\title{
Comparison of six methods for the extraction of lipids from serum in terms of effectiveness and protein preservation
}

\author{
T.P.L. Ferraz ${ }^{\mathrm{a}, \mathrm{b}}$, M.C. Fiúza ${ }^{\mathrm{a}, \mathrm{b}}$, M.L.A. dos Santos ${ }^{\mathrm{b}}$, \\ L. Pontes de Carvalho ${ }^{\mathrm{a}}$, N.M. Soares ${ }^{\mathrm{b}, *}$ \\ ${ }^{a}$ Centro de Pesquisa Gonçalo Moniz, Fundação Oswaldo Cruz, Salvador, Bahia, Brazil \\ b Departamento de Análises Clínicas e Toxicológicas, Rua Barão de Geremoabo s/n, Faculdade de Farmácia, \\ Universidade Federal da Bahia, Campus de Ondina, Salvador, Bahia 40170115, Brazil
}

Received 14 August 2003; received in revised form 30 September 2003; accepted 20 October 2003

\begin{abstract}
The present work compares six biochemical methods for extraction of lipids from human serum. Although some organic solvents were good lipid extractors, they precipitated most of the total proteins and albumin. On the other hand, methodologies using Triton X-114 and silica were efficient for extraction of lipids, while sparing the protein fraction.
\end{abstract}

(C) 2003 Elsevier B.V. All rights reserved.

Keywords: Lipid extraction; Proteins; Organic solvents; Silica; Detergent

\section{Introduction}

The mammalian serum, i.e. the fluid phase of the coagulated blood, is constituted by water, electrolytes, proteins, lipids, carbohydrates, amino acids, vitamins, hormones and excreted metabolites, such as urea and uric acid [1].

The study of serum or plasma components usually demands either methods of purification or depletion of one or more molecules. Some methods can be used with this aim, such as affinity chromatography on sorbent columns and chromatography based on differences in solvent solubilities. However, the latter methods can modify the ratio of more than one serum constituent, as these constituents possess, in varying degrees, both polar and non-polar groupings.

* Corresponding author. Fax: $+55-71-2457865$.

E-mail address: neci@ufba.br (N.M. Soares). 
Biological lipids constitute a group of substances that have insolubility in water as a characteristic feature [2] and play many important physiologic roles, such as functioning as a substrate for synthesis of bile acid and steroid hormones [3]. They are also a source of energy, mainly as chylomicrons and very low density lipoproteins (VLDL), which have relatively large proportions of triacylglycerols in their composition [4].

As lipids are insoluble in water, a chloroform -methanol mixture is the solvent commonly used to extract them [5-7]. Chloroform extracts mainly neutral lipids (triglycerides, waxes and pigments), while methanol extracts cell-membrane lipids (phospholipids, glycoproteins and cholesterol). Hexane or hexane-isopropanol can also be used to remove neutral lipids [8-10]. In addition to extraction using organic solvents, absorption on hydrophobic affinity columns and detergent precipitation methods can also be used to remove lipids from biological samples [11 12$]$.

The objective of this work is to compare six methods for extracting lipids from human serum, in terms of their efficacies and effect on total protein content.

\section{Materials and methods}

\subsection{Human serum}

Serum samples were prepared from blood samples collected from informed healthy laboratory volunteers.

\subsection{Serum lipid extraction with organic solvents}

Extraction with a chloroform-methanol mixture was based on the methodology of Folch et al. [7]. Briefly, $1 \mathrm{ml}$ of normal human serum was added to $10 \mathrm{ml}$ of chloroformmethanol 2:1 (v/v). The mixture was agitated manually for $20 \mathrm{~s}$ and centrifuged at $2500 \times g$ for $10 \mathrm{~min}$ at $20{ }^{\circ} \mathrm{C}$. After centrifugation, the aqueous phase was collected and stored at $-20{ }^{\circ} \mathrm{C}$ for posterior analysis.

Extractions with hexane and hexane-isopropanol were carried out according to the methodologies of Baldoni et al. [8] and Sugiyama et al. [9], respectively, with some modifications. Briefly, serum was mixed with hexane or with a mixture of $6.0 \mathrm{ml}$ of hexane and $3.0 \mathrm{ml}$ of isopropanol at a ratio of $1: 10(\mathrm{v} / \mathrm{v})$, agitated manually for $20 \mathrm{~s}$ and then centrifuged at $2500 \times g$ for $10 \mathrm{~min}$ at $20{ }^{\circ} \mathrm{C}$. The aqueous phase was collected and stored at $-20{ }^{\circ} \mathrm{C}$. In the extraction procedure using only hexane, the aqueous phase was collected and subjected to two subsequent identical extraction steps.

For ether extractions, normal human serum was mixed with $100 \%$ ether in the ratio of 1:10 (v/v). The mixture was agitated manually for $20 \mathrm{~s}$ and centrifuged at $2500 \times g$ for 10 min at $20{ }^{\circ} \mathrm{C}$. This step was repeated three times with the aqueous phase.

\subsection{Detergent extraction}

This was carried out according to a modification of Bordier's [12] methodology. Briefly, serum was mixed 2:1 (v/v) with previously washed Triton X-114 and 
incubated for $10 \mathrm{~min}$ at $4^{\circ} \mathrm{C}$, followed by $5 \mathrm{~min}$ at $37{ }^{\circ} \mathrm{C}$. The mixture was then centrifuged at $12000 \times g$ for $15 \mathrm{~min}$ at $4^{\circ} \mathrm{C}$, and the upper layer was collected, mixed again with Triton X-114 at a ratio of 10:1 (v/v), incubated and centrifuged as described above. The upper layer was then collected and stored at $-20{ }^{\circ} \mathrm{C}$, for posterior analysis.

\subsection{Silica extraction}

This was carried out according to a modification of Neoh et al.'s methodology [13].

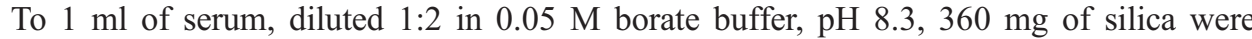
added (Sigma, St. Louis, USA). The mixture was incubated for $2 \mathrm{~h}$ at $4{ }^{\circ} \mathrm{C}$, under constant agitation. It was then centrifuged at $2500 \times \mathrm{g}$ for $10 \mathrm{~min}$ at $4{ }^{\circ} \mathrm{C}$. A total of 360 $\mathrm{mg}$ of silica was again added to the supernatant and the mixture was incubated for $1-16$ $\mathrm{h}$, followed by centrifugation, as described above. The supernatant was stored at -20 ${ }^{\circ} \mathrm{C}$ for posterior analysis.

\subsection{Determination of lipid and protein concentrations}

Cholesterol and triglyceride levels were determined with enzymatic assays based in the Trinder reaction (Labtest Diagnóstica, Lagoa Santa, Brazil). Albumin concentrations were determined by chromogenic reaction with bromocresol green and total protein concentrations by means of the biuret reaction.

\subsection{Calculation of lipid extraction efficacy and protein/lipid purification ratio}

The percentage of lipid extraction was calculated by means of the following formula:

$\%$ of lipid extraction

$$
=100-\frac{\text { triglycerides or cholesterol serum concentration after lipid extraction } \times 100}{\text { triglycerides or cholesterol serum concentration before lipid extraction }}
$$

The protein/lipid purification ratio indicates the extent to which protein was purified, in relation to lipid, after lipid extraction, i.e., how many folds the total protein concentration increased in relation to the lipid concentration (triglycerides + cholesterol). It was calculated with the help of the following formula:

$$
\begin{aligned}
& \text { Protein } / \text { lipid purification ratio } \\
& =\frac{\text { concentration of protein in extracted serum } \times \text { concentration of lipid in original serum }}{\text { concentration of protein in original serum } \times \text { concentration of lipid in extracted serum }}
\end{aligned}
$$

\section{Results}

In order to determine the best conditions for specific lipid extraction with silica, a second absorption with new silica was carried out for different time periods (from 1 to $16 \mathrm{~h}$ ). A second incubation of the serum with silica for $4 \mathrm{~h}$ led to nearly maximal cholesterol 


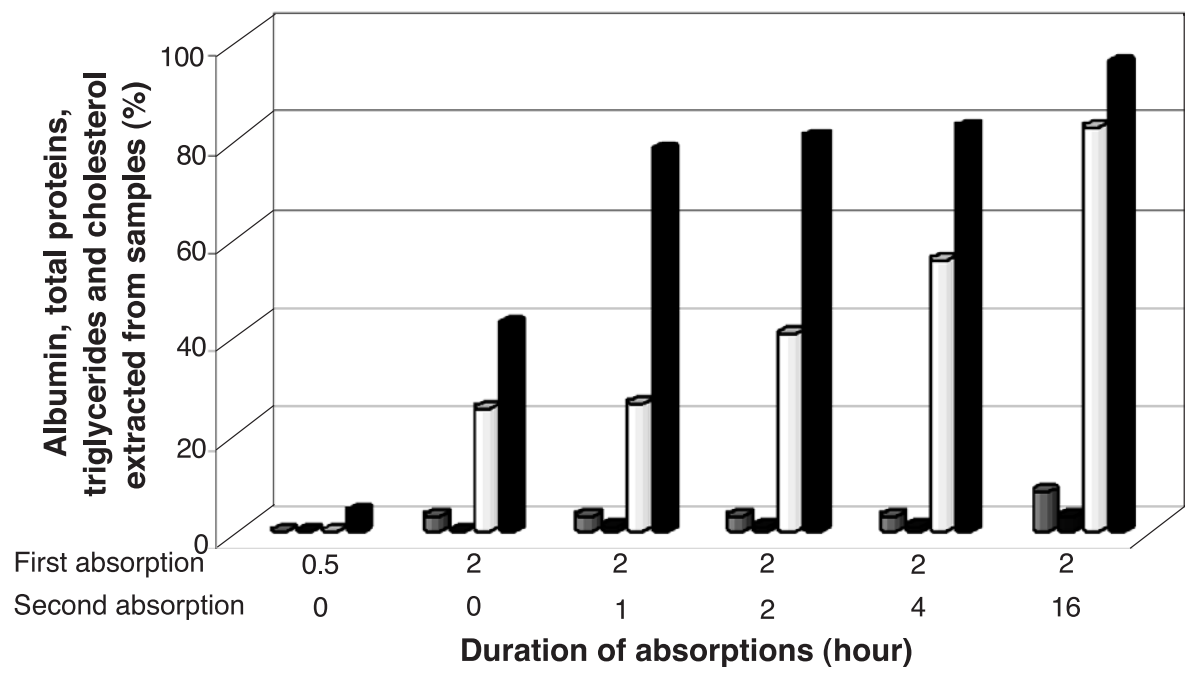

Fig. 1. Extraction of albumin (溉), total proteins (国), triglycerides ( $\square$ ) and cholesterol ( $\square$ ) from serum by absorption with silica. After a first absorption with silica, the serum was further extracted by a second absorption with new silica, for the time periods indicated in the $x$-axis. The data represented by the first set of four columns, resulting from 0.5 -h incubation with silica, were produced according to the original Neoh and collaborators' methodology.

extraction, whereas triglyceride extraction still improved with a second 16-h incubation (Fig. 1). Using the 16 -h incubation, $94 \%$ of cholesterol and $71 \%$ of triglycerides were removed (Table 1 and Fig. 2A).

Table 1

Concentrations of total protein, albumin, triglycerides and cholesterol in human serum before and after extraction of lipids

\begin{tabular}{|c|c|c|c|c|c|}
\hline \multirow{2}{*}{$\begin{array}{l}\text { Extraction } \\
\text { method }^{\mathrm{a}}\end{array}$} & \multicolumn{5}{|c|}{ Concentration of ( $\%$ of original amount $)$} \\
\hline & Total protein & Albumin & Triglycerides & Cholesterol & $\begin{array}{l}\text { Proteins/lipid } \\
\text { purification ratio }\end{array}$ \\
\hline None & $6.4 \pm 0.2^{\mathrm{c}}(100.0)$ & $3.8 \pm 0.2^{\mathrm{c}}(100.0)$ & $100 \pm 8.0^{\mathrm{d}}(100.0)$ & $231 \pm 58^{\mathrm{d}}(100.0)$ & 1.0 \\
\hline $\begin{array}{l}\text { Chloroform- } \\
\text { methanol }\end{array}$ & $0.3 \pm 0.1(7.8)$ & $0.4 \pm 0.1(10.5)$ & $13 \pm 1.7(13.0)$ & $3 \pm 1.0(1.0)$ & 1.4 \\
\hline Hexane & $5.7 \pm 0.4(89.1)$ & $3.3 \pm 0.1(86.8)$ & $82 \pm 10.2(82.0)$ & $184 \pm 36(80.0)$ & 1.1 \\
\hline Triton X-114 & $6.3 \pm 0.2(98.4)$ & $3.7 \pm 0.1(97.4)$ & $19 \pm 4.0(19.0)$ & $76 \pm 8.3(32.9)$ & 3.4 \\
\hline Ether & $5.9 \pm 0.5(92.2)$ & $3.5 \pm 0.1(92.1)$ & $96 \pm 10.0(96.0)$ & $157 \pm 41.9(68.0)$ & 1.2 \\
\hline $\begin{array}{l}\text { Hexane- } \\
\quad \text { isopropanol }\end{array}$ & $0.5 \pm 0.1(7.8)$ & $0.2 \pm 0.1(5.3)$ & $44 \pm 5.9(44.0)$ & $19 \pm 1.2(8.2)$ & 0.4 \\
\hline Silica & $6.3 \pm 0.2(98.4)$ & $3.6 \pm 0.1(94.7)$ & $28 \pm 2.5(28.0)$ & $17 \pm 1.2(7.4)$ & 7.2 \\
\hline
\end{tabular}

${ }^{a}$ The extraction methods were based on the use of the material listed in the first column, as described in Section 2 .

${ }^{\mathrm{b}}$ This ratio shows how many folds the total protein concentration varied in relation to the lipid concentration (triglycerides + cholesterol); 1 = no variation.

${ }^{\mathrm{c}}$ Mean of three independent determinations \pm standard deviation of the mean, expressed as $\mathrm{g} / 100 \mathrm{ml}$.

${ }^{\mathrm{d}}$ Mean of three independent determinations \pm standard deviation of the mean, expressed as $\mathrm{g} / \mathrm{l}$. 
(A)

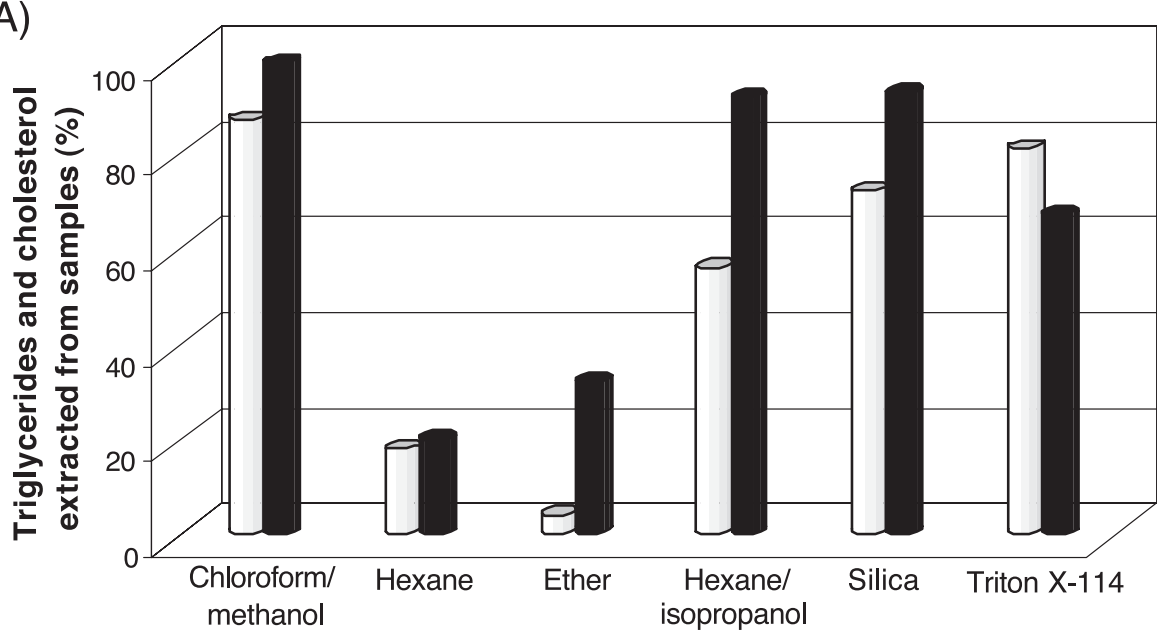

(B)

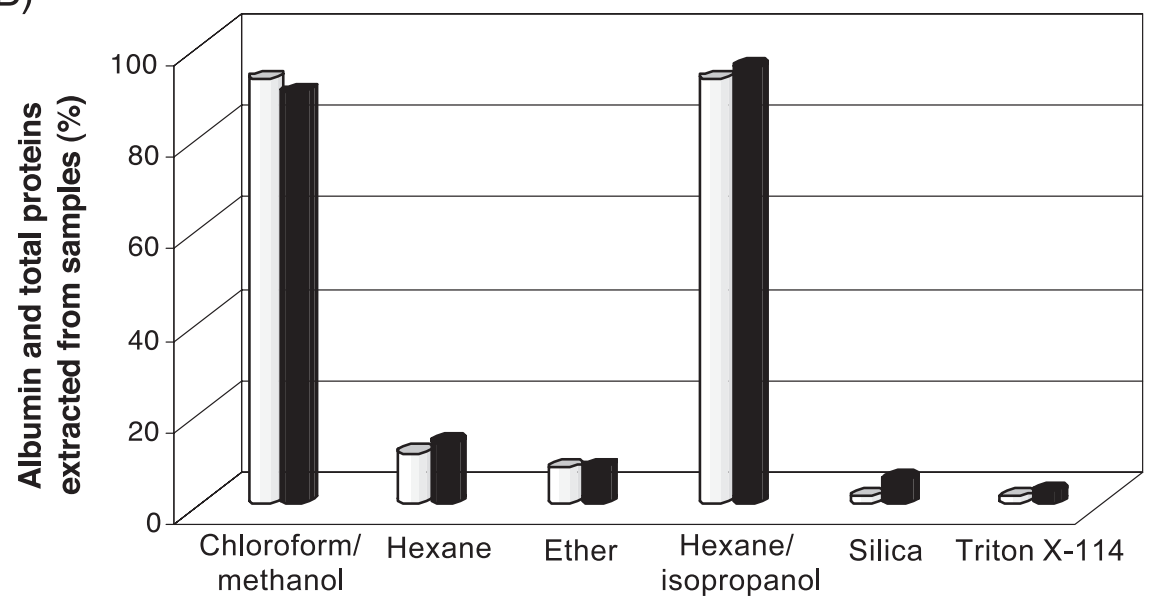

Extraction Methods

Fig. 2. Proportion of cholesterol, triglycerides, albumin and total proteins, removed from human serum by six different methods. The methods were based on extraction/absorption with the substances indicated in the $x$-axis, as described in Section 2. The data are representative of three experiments. The extraction with silica was done by two successive 2- and 16-h incubations with new silica. ( $\square$ ) $\%$ of removed triglycerides (A) or total proteins (B); (匹) \% of removed cholesterol (A) or albumin (B).

Chloroform-methanol extracted $90 \%$ of the triglycerides and $99 \%$ of the cholesterol, hexane-isopropanol removed $53 \%$ of the triglycerides and $94 \%$ of the cholesterol, ether removed $1.9 \%$ of the triglycerides and $31 \%$ of the cholesterol, and hexane removed $2 \%$ of triglycerides and $25 \%$ of the cholesterol (Table 1 and Fig. 2A). Triton X-114 removed $73 \%$ of triglycerides and $90 \%$ of the cholesterol (Table 1 and Fig. 2A). 
The different methods varied in terms of protein-precipitation activity. Chloroformmethanol and hexane-isopropanol precipitated the majority of the serum protein, whereas the serum proteins were preserved when the other methods were deployed (Table 1 and Fig. 2B).

\section{Discussion}

Usually, complex mixtures of lipids are fractionated according to polarity or to solubility in different solvents [5]. Neutral lipids have low polarity and therefore are best extracted by solvent with hydrophobic characteristics, such as chloroform and ether [2]. Yet, membrane amphypatic lipids are efficiently extracted by more polar solvents, like ethanol and methanol [2]. These, in addition to reducing hydrophobic interactions, interfere with intra- and inter-molecular hydrogen bridges [3].

Most serum lipids behaved as polarized lipids, in that they were readily extracted by chloroform-methanol and hexane-isopropanol mixtures. However, these solvents are not selective: they also precipitated a great amount of total proteins and albumin. On the other hand, extraction with ether and hexane precipitated very little proteins but did not remove much of the lipids.

The extraction method using silica, described by Neoh et al. [13], which involves a 30-min absorption step, did not efficiently remove lipids from human serum. This was only attained when the silica concentration was raised ten times, in two consecutive absorption steps lasting 2 and $16 \mathrm{~h}$. It is possible that the lipid amounts in the samples used by Neoh et al. [13] were smaller than those usually found in human serum.

The use of Triton X-114 also resulted in efficient serum lipid extraction. Lowering the temperature of the serum and Triton X-114 mixture causes the formation of insoluble micelles, containing the detergent and hydrophobic/amphiphylic molecules. The small amount of precipitated serum proteins with the insolubilized Triton X-114 derives from the fact that amphiphylic proteins appear in small amounts in human serum [12].

Contrasting with the extractions with organic solvents, the modified silica-based and the Triton X-114 precipitation methods removed most lipids and preserved most of the protein. Indeed, the protein enrichment in the serum treated with silica or Triton X-114, relative to the lipid content, was 7.2 and 3.4 folds, respectively, whereas the protein enrichment obtained with the use of the organic solvents ranged from only 0.4 to 1.4 folds. The two former methods, therefore, should to preferred over the methods employing organic solvents for lipid extraction, with protein preservation, from mammal serum.

\section{Acknowledgements}

This work was supported by the Conselho Nacional de Desenvolvimento Científico e Tecnológico-CNPq, Brazil. We thank Eduardo A. Bari for a critical reading of the manuscript. 


\section{References}

[1] Berne RM, Levy MN. Fisilogia. Rio de Janeiro: Guanabara Koogan; 1996.

[2] Lehninger AL, Nelson DL, Cox MM. Princípios de bioquímica. Sarvier, São Paulo; 2000.

[3] Stayer L. Bioquímica. Rio de Janeiro: Guanabara Koogan S.A.; 1996.

[4] Devlin TM. Manual de bioquímica com correlações clínicas. São Paulo: Edgar Blucher; 1998.

[5] Bligh EG, Dyer WJ. A rapid method of total lipid extraction and purification. Can J Biochem Physiol 1959;911(8):917-37.

[6] Sperry WM, Brand FC. The determination of total lipids in blood serum. J Biol Chem 1955;69:77-213.

[7] Folch J, Lees M, Stanley GMS. A simple method for the isolation and purification of total lipids from animal tissues. J Biol Chem 1957;467:226-509.

[8] Baldoni E, Bolognani L, Vitaioli L. A rapid procedure for elimination of non-polar lipids hampering the usual polar lipid extraction and TLC separation. Eur J Histochem 1995;253(4):239-57.

[9] Sugiyama E, Hara A, Uemura K. A quantitative analysis of serum sulfatide by matrix-assisted laser desorption ionization time-of-flight mass spectrometry with delayed ion extraction. Anal Biochem 1999;90(1):97-274.

[10] Boselli E, Velazco V, Caboni MF, Lercker G, Pressurized liquid extraction of lipids for the determination of oxysterols in egg-containing food. Journal Cromatograph. 2001;239(1-2):244-11, 917.

[11] Harvey PR, Upadhya GA, Strasberg SM. Cholesterol microcrystals associated with concanavalin A binding glycoproteins contribute artifactually to nucleating activity assays. J Lipid Res 1995;2661(12):2636-69.

[12] Bordier C. Phase separation of integral membrane proteins in Triton X-114 solution. J Biol Chem 1981;1604(4):1256-607.

[13] Neoh SH, Gordon C, Potter A, Zola H. The purification of mouse monoclonal antibodies from ascitic fluid. J Immunol Methods 1986;231:235-91. 